\title{
Availability of Municipal Services as a Means of Communication of Municipal Authorities and Citizens
}

\author{
Olga V. Yakhina ${ }^{1}$, Nikita S. Vavilov ${ }^{1} \&$ Denis S. Mikheev ${ }^{1}$ \\ ${ }^{1}$ Mari State University, Yoshkar-Ola, Russia \\ Correspondence: Olga V. Yakhina, Mari State University, 1, Lenin sq., Yoshkar-Ola, Mari El Republic, Russia. \\ E-mail: olgeens@mail.ru
}

Received: February 21, 2015

Accepted: March 15, 2015

Online Published: April 29, 2015

doi:10.5539/res.v7n8p227

URL: http://dx.doi.org/10.5539/res.v7n8p227

\begin{abstract}
The article presents the issues of an increasing degree of municipal services availability for the population of the Russian Federation. The team of authors analyses in detail such categories as "municipal service", "administrative provision", "civil society". This article attempts to provide the recommended practices for the improvement of degree of transparency, openness, and publicity of the mechanisms for the exercise of civil rights in the sphere of municipal services provision, which increases the number and availability of services for the population as a result. On the basis of the analysis of different theories in Russian and foreign legal science the authors demonstrate nonseparability of the local self-government bodies and civic institutions in the process of provision of services and public monitoring of their provision.
\end{abstract}

Keywords: municipal service, availability, publicity, local community, administrative provision, electronic municipality, civil society, citizen

\section{Introduction}

The development of democracy in the state and establishing of civic institutions interrelate closely: the more civil society in the state is developed, the more democratic the state becomes. Civil society is one of the sources of public authorities legitimacy, as it is civic institutions which hold information on the state of political, social, economic, and cultural sphere of public life in the state. The state cannot exist without civil society, as well as civil society cannot function without the state. A high level of development of civil society provides "availability" of state for citizens, feedback between a citizen and governmental bodies. In its turn, local self-government is a link between a state and civil society, because self-government means population shall deal with the matters of local significance on their own. Therefore, speaking of availability of the state for citizens we mean, first of all, availability of local self-government and all its elements for the local community. Activity of citizens of the Russian Federation in solving of issues on the local and national levels regularly becomes a matter of discussion on the federal level as well.

Thus, in his Annual Address to the Federal Assembly of the Russian Federation of December 4, 2014 President of Russia V.V. Putin declared the following: "We can see how active citizens are and what constructive efforts they are taking. Not only are they highlighting issues for the authorities to tackle, they also actively participate in settling issues and problems. They realise full well that much depends on their personal efforts." (Presidential Address, 2014)

Evaluating the reform of local self-government and federal law of 06.10.2003 \# 131-FZ "On General Principles of Organization of Local Self-Government in the Russian Federation" the Russian Federation Civic Chamber points out that they "did not succeed in the most significant aim of the reform-involving of citizens into active solution of the matters of local significance and establishing of civic institution" (Report on the State of Civil Society of the Russian Federation for 2014).

As noted by All-Russian Public Organization "All-Russian Council for Local Government Development" (http://vsmsinfo.ru/pdf/zh2013/vsms8.pdf) in their annual report, civic initiative in the Russian municipalities cannot be called developed. Among the reasons of contextual, non-systemic character of citizens' participation in exercising local self-government by this organization it is necessary to mention the following:

- Slow rate of social and economic development of municipal entities; 
- Absence of solid financial base for civic engagement, economic weakness of municipal entities;

- The existing management system where local authorities depend on higher-level state authorities rather than on citizens;

- Imperfection of legal mechanisms regulating the participation of citizens in solution of matters of local significance.

It is the author's opinion that the development of institution of municipal services, in other words the procedure of provision of public goods by the local self-government bodies to the population of any territory, is able to improve in many ways the development of civil society, strengthen credibility of local authorities, and raise the level of publicity, public control, and initiative.

\section{Methods}

The methodological basis of studies is a systematic, complex approach to the analysis of provision processes of municipal services availability for the local community. As a part of the study of procedures and authorities of the local self-government bodies in adopting administrative provisions for municipal services provision, as well as problems of availability and public control in this sphere, the following methods were used: common philosophical method, general scientific cognitive methods (dialectical, systematic, analysis and synthesis, induction and deduction), as well as specific scientific methods (legal comparative, legalistic, legal historical, sociological, systemic functional, statistical, theoretical forecasting, legal linguistics methods).

In particular, legalistic method was used for the research of legal confirmation problems of administrative provision status in the system of municipal regulations, legal comparative method-when considering legal confirmation of local self-government in the Russian Federation and in foreign countries; theoretical forecasting method - in the preparation of the recommendations on the creation of mechanisms of municipal services availability for the citizens in the country.

The use of dialectical method allowed accomplishing systemic analysis of the peculiarities of regulatory and legal confirmation of elaboration and adoption procedures for municipal regulations controlling the matters of municipal services provision. Legal comparative, systemic functional and legal historical methods allowed eliciting features of local self-government functioning in Russia and abroad. Different research methods helped to reveal the trends and peculiar features of statutory regulation of publicity mechanisms in the work of the local self-regulating bodies on municipal services provision, as well as state definite legislative proposals in the sphere of control of their activity.

The material for the study of the topical issue brought up in the article was the Russian Legislation, works of Russian legal scholars and the results of foreign scientific studies in the field of local self-government.

\section{Results}

The authors obtained mixed results of research described in brief as follows. The institution of municipal services in the Russian Federation has recently got its full-fledged legislative recognition that is why the practice of municipal services provision is at the stage of formation. Municipal services are available to the population only on the surface, because their main provision principles, which include publicity, are at the stage of formation, they are not practically enshrined in law and are seldom applicable because of amorphia of civil society. If to compare with foreign countries (Canada), such situation was the case decades ago, but as Russia wants to be a successful member of the international community, it needs to provide quick reforming of the sphere of local relations. By the example of the foreign countries it is necessary to make a point of publicly-disclosed funding of municipal services, public control of financial matters, citizens' participation in financial planning. The development of public basis of local self-government will promote alterations in the economic situation at the local level in many ways (Jun, 2014).

Positive evaluation may be given to the public authority initiative on the introduction of electronic municipality into Russian municipal practice which is intended to ensure availability and publicity of municipal services for the society. The authors lobby for a wide use of electronic municipality both for publication of statutes and regulations and their drafts with the possibility of their public discussion and as a means, one of the ways of municipal services provision. Citizens' access to municipal goods and possibility of broad public control are based on the principles of publicity, openness and transparency. The population has the right to know financial information at the local level and get municipal services regardless of the political situation in the country, size of municipal entity or other factors. For the present-day development of municipal relations the scientific studies of the foreign research workers are of indisputable value. It is necessary to conduct such research within the territory of the Russian Federation. 


\section{Discussion}

For the convenience of research the chosen topic was discussed in three aspects: availability problems in terms of publicity, the peculiarities of legal control of municipal services in Russia and forming of civil society at the local level. A great deal of scientific works is devoted to the specified scientific fields, which led authors to the following arguments and conclusions.

As justly noted by D. S. Mikheev, "such form of direct participation of citizens in solving the matters of local significance, as local referendums, voting for recall of deputies and elected officials of local self-government are not almost used in practice. The population shows no interest in the mentioned municipal problems" (Mikheev, 2013). In its report the Civic Chamber of Russia highlights the following problems of the development of local self-government preventing the dialogue with civil society: "the reform of local self-government complicated the system artificially, generated global lack of funding of municipal functions, formally exonerated the state from responsibility for their execution, generated doubling and mixture of competences of the local self-government entities of different levels and government authorities of the constituent entities of the Federation" (Report on the State of Civil Society of the Russian Federation for 2014.)

Such situation of the development of local self-government and citizens' initiatives reminds to a large extent a situation created in some foreign countries decades ago, an example of such description may be found in the work by David Siegel "Provincial-municipal relations in Canada: an overview": "Local government came to Canada slowly and with great difficulty. In general, municipal organization in Canada has been opposed by established elites who feared popular control of these new governments and by the citizenry in general who viewed local government as simply another source of taxation" (Siegel, 2008).

Under current conditions of the Russian statehood civic institutions are being formed and established, and because of underdevelopment they cannot exercise efficient control over the public authorities in power. However, there are the pronounced trends towards the strengthening and growth of the role of civil society in the mechanism for the exercise of rights and freedoms of the person and of the citizen in the Russian Federation.

One of the prospective forms of activity at the municipal level is public control of the local self-government bodies. Citizens are interested in control of those authorities of the local self-government bodies which have a direct influence on their life-sustaining activity.

In Russia such sphere of functions of local self-government is united into the institution of municipal services. An individual legal act is devoted to the sphere concerned-Federal Law \# 210-FZ of July 2, 2010 "On the Organization of Provision of the State and Municipal Services". This law established that "the municipal service provided by local self-government body is the activity on the implementation of the functions of local self-government body which is performed on requests of applicants within powers of the body providing municipal services, in the solution of the matters of local significance established according to the Federal Law of October 6, 2003 \# 131-FZ "On General Principles of the Organization of Local Self-Government in the Russian Federation" and charters of municipalities". The law warrants an individual regulatory act intended to control the sphere of such legal relations - this is an administrative provision. "Even with all things considered an undisputable enthusiasm is induced both by the probability of adoption of this regulatory act, as before issue of the Federal Law \# 210-FZ the "provision" together with documentation management regulations, internal code of labor conduct, duty regulations and other similar acts was considered exceptionally local law act, and the fact that this regulatory act is understood in the criteria of inaccessibility of terminological clearness, definite legal control, and the procedure of its approval" (Shabadarova, 2014). As mentioned by T. N. Mikheeva, "the local self-government bodies, like government authorities, have the corresponding number of public authorities powers, without which it is impossible to govern" (Mikheeva, 2012). We can't but agree with such statement, and the structure of the Russian power apparatus included these new acts with the help of the law into the mechanism of implementation of powers of authority by the local self-government bodies. Consequently, administrative provisions of the local self-government bodies are regulatory acts establishing the rules of procedure on the implementation of the functions of local self-government body which is performed on requests of applicants within powers of the body providing municipal services, in the solution of the matters of local significance established according to the legislation of Russia and charters of municipalities.

At the same time, in spite of the legislative recognition of the mechanisms of municipal services provision, the availability issue remains unclear. Because of the absence of initiative and lack of familiarity with their legal rights the citizens often decline to exercise the right for municipal services provision. But there are the situations when the applicants face administrative burdens on the way toward their goal. Therefore, the administrative provision of the local self-government bodies turns from the "catalyser" into the main brake. The foreign studies 
scratch just the surface of the topic concerning such situations, as the municipal services sphere of those countries is functioning by default due to a high degree of development of civil society and openness of public authorities. In our country this problem is especially acute, because both civil society and mechanisms of municipal services provision are in the state of development and even have not reached the state close to satisfactory. Thus, the researches underline insufficient development of publicity principle in theory and practice of the organization of local self-government. D. S. Mikheev notes: "Consequently, modern states as a basic fundamental principle in the legal regulation of local government put the publicity at the forefront, as a tool linking the local authorities with the residents of municipalities" (Mikheev, 2014). According to the authors, the publicity principle is undoubtedly connected with the notion of "availability" of municipal services, to be more exact, it is a basis of this notion, and together with some other categories it composes this notion.

Regarding the availability of municipal services, first of all we mean the availability of a regulatory act controlling this institution that is the availability of administrative provisions of the local self-government bodies which consists of three elements. The first of them is publicity of administrative provisions of the local self-government bodies which means the disclosure of information to indefinite range of people appearing as a procedure for adoption of the specified acts by municipal bodies, especially at the stage of disclosure of the regulatory act.Openness is the availability of information on the specified regulatory acts for anybody who wants. This feature is connected with the forms of awareness of the population with the acts, specifically their disclosure (or publishing) in one or several publicly available sources.

Transparency as a peculiarity of administrative provisions of the local self-government bodies is demonstrated in real publicity and free familiarization with information, absence of political constituent and populism in regulations, their compliance with objective reality and legal needs. In respect to transparency a good conclusion that "form of government significantly affects the provision of municipal services and the influence of political activities and special interest groups on municipal decisions of cities and towns in this same population range" is made by P. Edward French in the article "Municipal Government: Does Structure Make a Difference in Small Cities and Towns?" (French, 2003). In other words, upholding the expressed position we summarize that the policy shall not influence making of legal decisions.

All three studied notions contain the category "pubic control". This control as such shall come from civic institutions. Concerning the research topic the most complete definitions of the notion "civil society" are the following. Chervonyuk defines modern civil society as a legal, liberal democratic, pluralist, open society, the main actor of which is a free individual pursuing his or her interests within laws and general procedures common for everybody (Chervonyuk, 2006). Perevalov denotes civil society as a democratic legal society oriented towards a certain person creating the atmosphere of respect for legal traditions and laws, and humanistic ideals, providing freedom of creative work and business activities, creating the possibility of well-being achievement and implementation of human and civil rights, generating seamless mechanisms of limitation and monitoring of state activities (Perevalov, 2008).

From this it follows that the main constituent of civil society, its structural element is a certain person having definite political, economic, social interests, his or her own position and being its active defender. In this case a citizen is involved into a complex system of legal relations; he or she is acting as a basis of civil society, a consumer of municipal services, and an actor of public control. Considering the contemporary trends of the Russian legislation on the way toward the satisfaction of needs of a citizen, it is necessary to pay attention to the adoption of modern technologies into the functioning of civil society, the institution of municipal services and publicity.

At the local level in Russia the term "electronic municipality" is used. It is not just an official site of municipal entity, it shall be understood as a mechanism of information exchange of the local self-government bodies with the population, civic institutions, different organizations on solving issues of local significance. Thus, $\mathrm{O}$. N. Vaneev describes electronic municipality as an information exchange of the local self-government bodies with the population and organizations using information and communication technologies, based on the principles of openness, availability and reliability of information on the activity of the local self-government bodies, freedom of legal search, obtaining, transfer, and distribution of information on the activity of the local self-government bodies, observance of citizens' privacy rights, freedom from interference with privacy and family, observance of right for protection of their honour and business reputation, right of organizations for protection of their business reputation if they supply the information on the activity of the local self-government bodies (Vaneev, 2010). Besides, we shall agree with D. Sivovolov who points out that "participating in the creation of "e-government" local self-government creates "local e-community". And for the creation of more efficient local community based on the modern telecommunication facilities the present municipal authorities have objective possibilities" 
(Sivovolov, 2010).

At the moment the use of the Internet in the interests of government authorities and local self-government bodies is not homogeneous. Moreover, differences in the use of Internet technologies may be expressed both in the issues regarding availability of the Internet in different regions of Russia and financial possibilities of municipalities. For the most of municipalities of Russia, especially at the level of urban and rural settlements, site creation and support, at least to define their existence in the Internet, is highly problematic because of great deficit of budget funds and absence of specialists in the sphere of site creation and support. As it is mentioned in the annual Report of the Russian Federation Civic Chamber, subsidies of the municipal entities make the heads dependent on higher authorities rather than on the population of its municipality (Report on the State of Civil Society of the Russian Federation for 2013). At the same time some government authorities of the constituent entities of the Russian Federation improve their site and portals beyond recognition almost every year presenting more modern and expensive solutions. Besides, as noted by O. S. Sokolova, "federal legislation in information sphere by no means refers to the Law on Local Self-Government. In this Law the regulatory issues of the activity of the local self-government bodies in the sphere of information do not reflect the tasks municipal entities face and do not stimulate the municipalities to perform the systematic activity on the formation of the base for "municipal e-government" (Sokolova, 2010). Ideally electronic municipality in the field of availability of municipal services shall provide:

1) Support of sites of municipal entities as the instruments of disclosure of regulatory acts, including administrative provisions.

2) Discussion of the drafts of regulatory acts.

3) Possibility to get municipal services remotely via the Internet (by exchange of electronic messages, video messages, download of special programmes, replacement of all real queues with electronic ones).

4) Posting of the reports on the activity of the local self-government bodies on the special websites with the possibility of public discussion and assessment of the activity of municipalities following the results of discussion (including on the forums and with the help of surveys).

5) Communication with local officials, municipal services via the Internet.

Meanwhile, in Russia all these forms are in the developmental and implementation stage. Incompletely implemented possibility of control on the part of civic institutions and insufficient financing also put brakes on the development of availability of municipal services for citizens. Foreign studies support this point of view. Thus, foreign science pays much attention to the financial issues which is right from our point of view. Jose A. Dorta-Velazquez, Javier de Leon-Ledesma and Jorge V. Perez-Rodriguez in the article "Models of Municipal Budget Allocation: Empirical Data from Spanish Municipalities" (Dorta-Velazquez et al., 2010) pay attention to the financial information when making decisions. The legal environment of municipal services provision shall include the bases of funding and financial planning. Funding reminds us again of the field of availability of these legal relations for the control on the part of civil society. The citizens shall know what they pay for and how efficiently their money will be used. At the same time openness of financial processes will raise interest and initiatives of the population of municipal entities. In the field of municipal construction Russia needs further research of social phenomena, something like the research made by Sven Rasegård in due time "Some Aspects of the Usefulness of Living Systems Theory in a Municipal Organization” (Rasegård, 1999).

\section{Conclusion}

During the study of the availability issues of municipal services in the Russian Federation the team of authors made a number of conclusions. The development of availability of the institution of municipal services in the Russian Federation is a powerful platform for the development of civil society, increase of citizens' activity at the local level. Taking into account limited experience of the functioning of the institution of municipal services in Russia, the principles of their provision, including publicity, are in the development stage, they do not have applicable regulations and are disclosed to the population very badly. However, at present time the development of such mechanisms as electronic municipalities will help to establish municipal policy on service provisions to the citizens more correctly and efficiently, it will allow to the local self-government bodies to be more flexible and mobile in the process of municipal services provision. The institution of public control for the activities of the local self-government bodies is worth noticing, which is aimed at prevention of abuse of power by municipal bodies due to citizens' initiatives, their ability to communicate with each other and public authority. For the moment due to the number of factors availability of municipal services to the population remains an open question, one of the solution of which is the development of social bases of local self-government. 


\section{References}

Address of President of the Russian Federation V. V. Putin to the Federal Assembly of 04.12.2014. (2014). Rossiyskaya Gazeta, 278.

Chervonyuk, V. I. (2006). Theory of Law and State (p. 638). Moscow.

Federal Law of 02. 07. 2010 \# 210-FZ. (2010). On the Organization of Provision of the State and Municipal Services. Retrieved from http://base.consultant.ru

Federal Law of 06. 10. 2003 \# 131-FZ. (2003). On General Principles of the Organization of Local Self-Government in the Russian Federation. Retrieved from http://base.consultant.ru

French, P. E. (2003). Municipal Government: Does Structure Make a Difference in Small Cities and Towns? Politics and Policy, 31(4), 694-725. http//dx.doi.org/10.1111/j.1747-1346.2003.tb00168.x

Siegel, D. (2008). Provincial-Municipal Relations in Canada: An Overview. Canadian Public Administration, 23(2), 281-317. http//dx.doi.org/10.1111/j.1754-7121.1980.tb00058

Jose A. D. -V., Javier de L. -L., \& Jorge V. P. -R. (2010). Models of Municipal Budget Allocation: Empirical Data from Spanish Municipalities. Public Budgeting \& Finance, 30(2), 24-46. http//dx.doi.org/:10.1111/j.1540-5850.2010.00955.x

Jun, H. -J. (2014). The Role of Municipal-Level Factors in Neighborhood Economic Change. Journal of Urban Affairs, 36(3), 447-464. http//dx.doi.org/10.1111/juaf.12036

Mikheev, D. S. (2014). Legal Analysis of the European Charter of Local Self-Government in the Light of the Principle of Publicity. Life Science Journal, 11(6), 619-622.

Mikheev, D. S. (2013). On the Directions of Democratization of Municipal Election Process. Municipal Services: Legal Matters, 1(3).

Mikheeva, T. N. (2012). The Peculiarities of the Contemporary Institution of Local Self-Government in the Russian Federation. Eurasian Law Journal, 2, 58-59.

Perevalov, V. D. (2008). Theory of Law and State (pp. 346-347). Moscow.

Rasegard, S. (2000). Some Aspects of the Usefulness of Living Systems Theory in a Municipal Organization. $\begin{array}{lllll}\text { Systems Research and Behavioral } & \text { Science, }\end{array}$ http//dx.doi.org/10.1002/(SICI)1099-1743(199901/02)16:1<57::AID-SRES297>3.0.CO;2-T

Report on the State of Civil Society of the Russian Federation for 2014. (2014). Russian Federation Civic Chamber (p. 184).

Report on work of All-Russian Public Organization. (2013). All-Russian Council for Local Government Development for 2013. Retrieved from http://vsmsinfo.ru/pdf/zh2013/vsms8.pdf

Shabadarova, O. V. (2014). An Administrative Provision as a Regulatory Act in the System of Municipal Regulations. Law and Justice, 11, 54-56.

Sivovolov, D. (2010). The Role of Municipal Authorities in the Creation of "e-government" in Russia. Municipal Authorities, 6(67).

Sokolova, O. S. (2010). Administrative and Legal Control of Municipal Information Relations. Administrative and Municipal Right, 9(90).

Vaneev, O. N. (2010). Electronic Municipality: Ways of Information Exchange of the Local Self-Government Bodies with the Population. Contemporary Law, 4(62).

\section{Copyrights}

Copyright for this article is retained by the author(s), with first publication rights granted to the journal.

This is an open-access article distributed under the terms and conditions of the Creative Commons Attribution license (http://creativecommons.org/licenses/by/3.0/). 